\title{
Mobilya endüstrisinde iş sağlığı ve güvenliği ile ilgili risk değerlendirmesi: Begonya mobilya imalat işletmesi örneği
}

\author{
Eyüp Aksoy ${ }^{1}$ iD, Hakan Keskin²* (D)
}

$\ddot{\mathbf{O} z}$

İş sağlığı ve güvenliği çalışmalarının temel felsefesi, iş kazaları ve meslek hastalıklarının meydana gelmediği bir çalışma ortamı oluşturmak, bu mümkün değilse; olabildiğince azaltmak ve çalışanlara daha sağlıklı bir iş ortamı sağlamaktır. İş sağ lığı ve güvenliği açısından yüksek riskler barındıran mobilya sektöründe, bu anlamda yeterince çalışma yapılmadığı görülmektedir. Bu çalışmada; mobilya üretim süreçlerinin, iş sağlı̆̆ ve güvenliği açısından ne gibi riskler taşıdığı ve bunlara yönelik çözümlerin neler olabileceği konusu incelenmiştir. Bu kapsamda, Afyonkarahisar 2. Küçük Sanayi Sitesinde mobilya üretimi yapan Begonya Mobilya firmasının bütün üretim süreçleri incelenmiş, işyerindeki tehlike ve riskler belirlenmiştir. Bunların birbiriyle ilişkisini belirlemek ve çözüm önerisi getirebilmek amacıyla, 5x5 L Tipi Matris Risk Değerlendirme Metodu kullanılmıştır. Tespit edilen risklerden bazıları; çalışma ortamının aydınlatılması, iklimlendirme, havalandırma, gürültü ve titreşim gibi fiziksel çevre faktörleri açısından yeterli olmaması, yangın algılama ve söndürme ekipmanlarının yeterli olmaması ve çalışma ortamının hacim olarak yeterli büyüklüğe sahip olmaması vb. şeklinde sıralanabilmektedir.

Anahtar Kelimeler: İş Sağllğı ve Güvenliği, Risk Değerlendirmesi, L Tipi Matris

\section{Occupational health and safety assessment in the furniture industry: Begonya furniture manufacturing example}

\begin{abstract}
If it is not possible to create a working environment where occupational accidents and occupational diseases do not occur, it is possible to reduce as much as possible and provide a healthier working environment for employees. In the furniture sector which has high risks in terms of occupational health and safety, it is seen that there has not been enough work in this sense. In this study, the question of what kind of risks in terms of occupational health and safety in the production processes of box type furniture, which is a furniture production method, and what can be the solutions for the mare examined. In this context, all production processes in a company that produces furniture in Afyonkarahisar were examined and the hazards and risks in the work place were determined. 5x5 L Type Matrix Risk Assessment Method, which is the most used method in risk assessment, was used in order to determine the relationship between them and to provide their solution. Some of the risks identified; The lack of adequate working environment lighting, air conditioning, ventilation, noise and vibration in terms of physical environment factors such as noise, fire detection and extinguishing equipment, lack of sufficient size of the working environment, etc. as it can be listed.
\end{abstract}

Keywords: Occupational Health and Safety, Risk Assessment, L Type Matrix 


\section{Giriş}

İş Sağlığı ve Güvenliği (İSG), Türkiye'de özellikle son yıllarda üzerinde oldukça fazla durulan bir konu haline gelmiştir. İSG kuralları, halen yasal zorunluluklarla uygulanmaya çalışılmaktadır. 30.06.2012 tarih ve 28339 sayılı Resmi Gazete'de yayımlanarak yürürlüğe girmiş olan 6331 sayılı İş Sağlığı ve Güvenliği Kanunu'nun 38. maddesinin 1. fikrasının (a) bendinin (2) numaralı alt bendine göre 50'den az çalışanı olan tehlikeli ve çok tehlikeli sınıfta yer alan işyerleri için bu kanunun getirmiş olduğu yükümlülükler 01.01.2014 tarihi itibariyle yürürlüğe girmiştir $\left(\mathrm{ÇSGB}_{1}, 2012\right)$.

Mobilya imalatı sektörü, 2016 yılı Sosyal Güvenlik Kurumu (SGK) verilerine göre, 99 faaliyet grubu sıralamasında; işyeri sayısı açısından 19'uncu, çalışan sayısı açısından 24'üncü sırada bulunmaktadır. Buradan bu sektörün, çalışma sıklığı bakımından tüm sektörler arasında önemli bir yere sahip olduğu anlaşılmaktadır. Mobilya imalatı sektörü, 26.12.2012 tarih ve 28509 sayılı Resmi Gazetede yayımlanan İş Sağlığı ve Güvenliğine İlişkin İşyeri Tehlike Sınıfları Tebliğine göre "tehlikeli” sınıftaki işyerleri arasında yer almaktadır (ÇSGB $\left.{ }_{2}, 2012\right)$.

Ford ve Tetrick (2011) yapmış oldukları çalışmada, bir çalışanın güvenliğinin organizasyonun yapısından bağımsız olarak, diğer mesleklere göre, daha büyük tehdit altında olabileceğini; geçmişte mesleksel yaralanma riskinin çalışanın tutum ve alışkanlıkları temelinde değerlendirildiğini, mevcut çalışmaların ise kişinin meslek özelliklerinden bağımsız olarak ölçülen mesleksel tehlikelerle ilgili olduğunu ifade etmekte; çalışanın mesleksel rolünün, beklenileni yapması ve yaptığı işin doğasında bulunan tehlikeler ölçüsünde genişletilebileceğini vurgulamaktadırlar.

Turan (2013), ahşap malzemeden mobilya üretimi yapan örnek bir tesiste iş faktörlerinden kaynaklanan çevresel etkilerin, çalışan sağlığı üzerinde oluşturacağ 1 etkileri tanımlamayı amaçladığı çalışmasında; mobilya üretiminin temel üretim süreçlerinde, çalışanın karşı karşıya kaldığı sağlık tehditlerini incelemiş, çalışanın sağlığına etki eden faktörlere ait iç ortam ölçümü sonuçlarından ve kişisel maruziyet değerlerinden yararlanarak, çalışanın hangi yolla sağlık zararına uğrayabileceğini tespit etmiştir.

Atılgan ve ark. (2015), Türkiye mobilya sektöründe iş kazaları ve meslek hastalıklarının seyri ve önlenmesine ilişkin öneriler sundukları çalışmanın sonucunda; mobilya işletmelerindeki iş kazaları ve meslek hastalıkların önlenmesine ilişkin; eğitim, zararsız hammadde kullanımı, teknolojiden etkin bir şekilde yararlanma, çalışma koşullarının iyileştirilmesi, ergonomik düzenleme, yangınla mücadele, iş hijyeni, makine koruyucular, psiko-sosyal tehlikelerle mücadele ve kişisel koruyucu donanımlarının kullanımının, öncelikli alınması gereken tedbirlerden olduğunu belirtmişlerdir.

Tor (2015), kap1 üretim sektöründe iş sağlığı ve güvenliği açısından çalışma yapacaklara bir altlık teşkil etmek, işletmelerinde risk analizi yaparak çalışan insanı, yürütülen işi ve ekonomik verimliliği sağlamalarında katk1 sunmayı amaçladığı çalışmasında, kap1 imalat sektöründe iş sağlığ 1 ve güvenliği açısından ortaya çıkabilecek tehlike ve riskleri analiz ederek; kabul edilebilir seviyelerde tutabilmek için alınması gerekli önlemleri araştırmıştır. Bu kapsamda; Amasya-Merzifon'da Platform Mobilya Sanayi ve Ticaret A.Ş.'ne ait tesislerde, kapı üretiminde olası tehlike ve riskleri "L Tipi Matris Risk Analizi" Metoduna göre değerlendirmiştir. Risk analizinde belirtilen tehlikelerin; personelin istenmeyen davranışları, işletme alanında personelin kişisel koruyucu donanım kullanmaması, aydınlatma elemanlarının bazı bölümlerde yetersiz kalması, personelin eğitim yetersizliği ve gürültülü ortamda çalışmaya maruz kalması olarak belirlemiştir. Risklerin ise; yaralanma, sakat kalma, el ve diğer uzuvların kesilmesi, ezilmesi, sıkışması, göz rahatsızlıkları ve işitme kayıpları olduğunu belirtmiştir. 
Uygun (2015), mobilya sektörünü iş sağllğ ve güvenliği açısından incelediği çalışmasında; biri yerel pazarda, diğeri uluslararası pazarlarda faaliyet gösteren iki mobilya işletmesinin, iş sağlığ 1 ve güvenliği kanununun yürürlüğe girmesini takiben karşılaştıkları iş kazaları açısından incelemiş ve iki işletme arasında karşılaştırma yapmıştır.

Yılmaz (2015), çalışmasında, Ankara ilinde faaliyet gösteren 9 mobilya firmasında incelemelerde bulunarak; bu firmalarda çalışan toplam 112 kişiyle anket çalışması gerçekleştirmiştir. Anket çalışmasının yanında, Fine-Kinney Risk Değerlendirme Yöntemini kullanarak yaptığ ${ }_{1}$ analizlerle, mobilya imalatı yapan işletmelerdeki iş güvenliği tedbirlerine yönelik durum tespiti yapmıştır. Yapılan çalışmalar sonucunda elde ettiği verileri dikkate alarak değerlendirmeler yapmış ve öneriler sunmuştur.

Akça (2016), Türkiye'de mobilya üretimi yapan işletmelerde iş kazalarına ve meslek hastalıklarına sebep olabilecek tehlike ve risklerin tespit edilmesini, bunların ortadan kaldırılabilmesi ve engellenebilmesi için çözüm önerilerinin getirilmesini ve bu alandaki işletmelerde uygulanan risk değerlendirmesi çalışmalarına katkı sağlanmasını amaçladığ çalışmasında; seçilen bir işletmede 3T Risk Değerlendirme Metodu kullanarak risk değerlendirme çalışmasını gerçekleştirdiği çalışma sonucunda; işyerinin, malzeme hazırlama bölümündeki güvenlik endeksini $\% 63$ ve malzeme işleme bölümündeki güvenlik endeksini \%49,1 olarak hesaplamış olup; her iki bölüm içindeki en tehlikeli modülün, "Kazalara Yol Açabilecek Tehlikeler" modülü olduğunu tespit etmiştir.

Koç (2016), çalışmasında, öncelikle iş sağlığ yönetim sistemi ve risk değerlendirmesi ve ergonomi kavramlarından bahsetmiş; ergonominin dünyada ve Türkiye'deki tarihsel gelişimini anlatmıştır. Daha sonrasında, işle ilgili kas iskelet sistemi rahatsızlıklarını çok yönlü olarak ele almış, literatürde yer alan ergonomik risk değerlendirme metotlarına yer vermiş, mobilya imalatındaki işe bağlı kas iskelet sistemi sorunlarına değinmiştir. Son olarak, tehlikeli sınıfta yer alan bir mobilya fabrikasında bunların uygulamasını gerçekleştirmiştir.

Şen ve Çınar (2017), mobilya yaşam döngüsü kapsamında, sektörde uygulanan iş güvenliği uygulamalarını, iş sağlı̆̆ı ve güvenliği sorunlarını; çalışma alışkanlıklarını, iş kazalarını, meslek hastalıklarını ve ortak yönlerini incelemiş, konu ile ilgili çözümlerin getirilmesini amaçlamışlardır. Bu doğrultuda; mikro, küçük, orta ve büyük ölçekli mobilya işletmelerine yönelik çalışanlar ve yöneticiler için iki farklı anket uygulamışlardır. Çalışma sonuçlarına göre; iş kazalarının azalması ve meslek hastalıklarının önlenmesi adına alınan tedbirler ve eğitimler için işletmelerin büyümesi gerektiğini, iş sağlığ ve güvenliği için mikro ve küçük işletmelerin birleşerek; büyümelerinin devlet tarafindan desteklenmesi gerektiğini vurgulamışlardır.

Bu çalışmada, mobilya imalatı sektöründe görülen ve görülme ihtimali olan iş kazası ve meslek hastalığına sebep olan etkenlerin irdelenmesi amacıyla; Afyonkarahisar 2. Küçük Sanayi Sitesinde yer alan Begonya Mobilya firmasındakiüretim süreçleri incelenmiş ve bu süreçlerin İSG yönünden etkileri tespit edilmeye çalışılmıştır. Böylece, mobilya sektörünün İSG açısından ne durumda olduğu ortaya konulmaya çalışılmış olmakla birlikte, küçük ve orta ölçekli işletmeler için İSG prensiplerinin belirlenebilmesinde kullanılabilecek bir referans kaynak niteliği taşıması sağlanmaya çalışılmıştır.

\section{Materyal ve Metot}

Araştırmada kullanılan işyeri, Afyonkarahisar 2. Küçük Sanayi Sitesinde faaliyet göstermektedir. İşyerinde, tabakalı ağaç malzemeden imal edilebilecek mobilyaların üretimi gerçekleştirilmektedir. Firmada, yaşları 15-45, eğitim seviyeleri ise ilkokul-lisans aralığında 
bulunan ve tamamı erkek olmak üzere toplam 15 çalışan görev yapmaktadır. İşyerinin kapalı alanı yeterli olmadığ 1 için işlerin aksamadan sistemli biçimde yürüyebilmesi açısından, kendi içinde bölümler oluşturulmuştur. Çalışma kapsamında, öncelikle işyerinin İSG açısından mevcut durumu hakkında bilgi toplanmıştır. $\mathrm{Bu}$ bilgiler ve işyeri birimlerinin ziyareti sırasında yapılan gözlemlerin ışığında, yapılan işe göre; genel, depo işleri, malzeme istifleme, makineler, küçük makineler, basınçlı kaplar, yönetim bürosu, montaj, mutfak, psiko-sosyal ve açık alanlar adı altında tehlike grupları oluşturulmuştur.

Araştırmada, 5x5 L Tipi Matris metodu yardımıyla risk değerlendirmesi yapılmıştır. Bu metodun seçilme nedeni, tek başına risk analizi yapan analistler için ideal olmasıdır. $\mathrm{Bu}$ metot, değişik prosesler içeren veya birbirinden çok farklı akış şemasına sahip işlerin hepsi için tek başına yeterli olmamakla birlikte; derhal ya da en kısa zamanda önlem alınması gerekli olan tehlikelerin tespiti için kullanılmaktadır. $\mathrm{Bu}$ metot ile öncelikle, bir olayın gerçekleşme ihtimali ile gerçekleşmesi halindeki sonucunun derecelendirilmesi ve ölçümü yapılmaktadır (Özkılıç, 2005). Burada, tehlike ve risklere ait olasılık (ihtimal) ve şiddet derecesinin çarpımından risk skoru değerleri (Risk Skoru = Olasılık x Zararın Şiddeti) elde edilerek Çizelgede 1'deki yerine yazılmaktadır (Bkz. Çizelge 1).

Çizelge 1. 5x5 L tipi risk değerlendirme matrisi (Erdim ve ark. 2010).

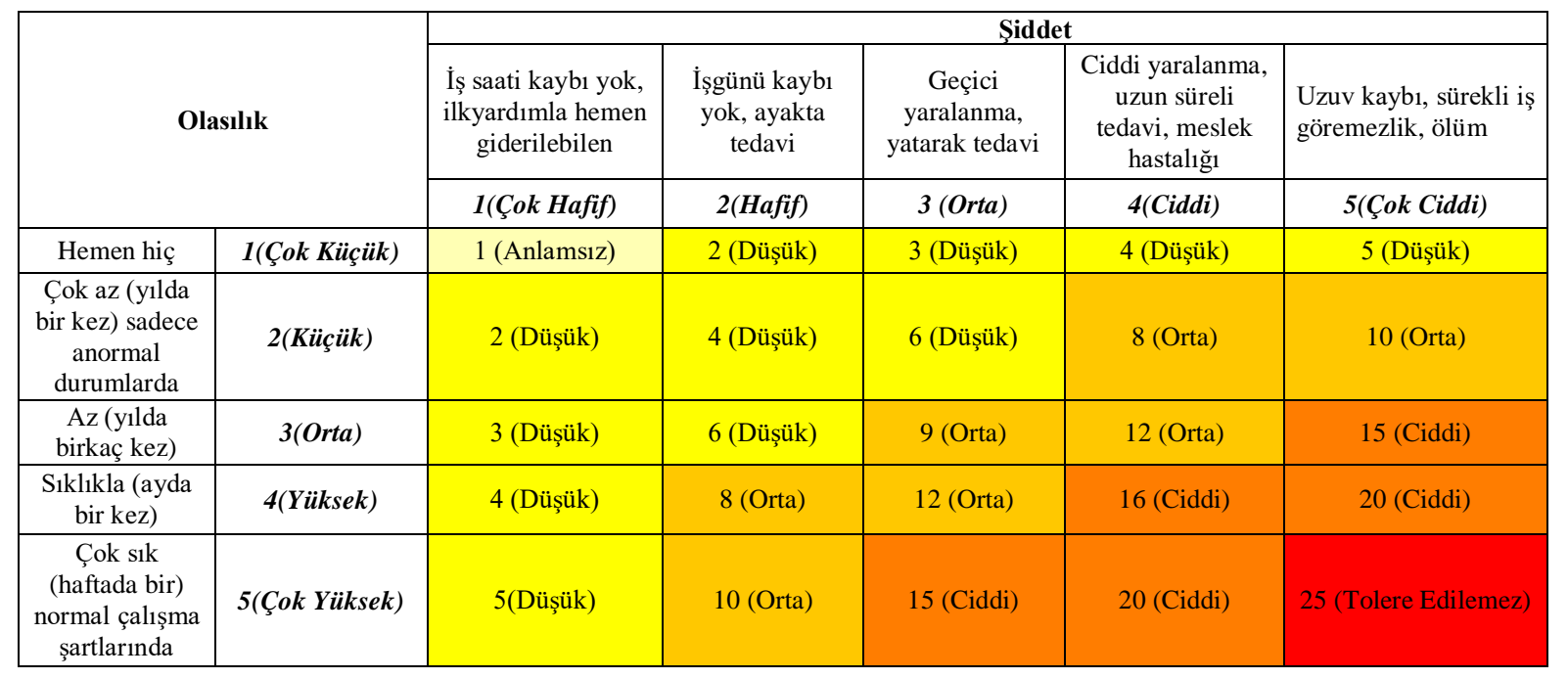

Çizelge 1.'den elde edilen değerler, risk değerlendirme tablosuna kaydedilir ve en yüksekrisk skoru değerinden başlanarak; riskler için gerekli önlemler alınır (Bkz. Çizelge 2).

Çizelge 2. $5 \times 5$ L tipi risk değerlendirme matrisindeki risk skoruna göre alınması gereken önlemler [Erdim ve ark. 2010].

\begin{tabular}{|c|c|l|}
\hline Risk Seviyesi & Risk Skoru & \multicolumn{1}{|c|}{ Alınması Gereken Önlem } \\
\hline Anlamsız & 1 & $\begin{array}{l}\text { Riskleri ortadan kaldırmak için kontrol prosesleri planlamaya ve gerçekleştirilecek faaliyetlerin } \\
\text { kayıtlarını saklamaya gerek yoktur. }\end{array}$ \\
\hline Düşük & $2,3,4,5,6$ & $\begin{array}{l}\text { Riskleri ortadan kaldırmak için ilave kontrol proseslerine gerek olmayabilir. Ancak mevcut kontroller } \\
\text { sürdürülmelidir. }\end{array}$ \\
\hline Orta & $8,9,10,12$ & Riskleri düsürmek için gerekli faaliyetler başlatılmalı ve en fazla 6 ay içinde tamamlanmalıdır. \\
\hline Ciddi & $15,16,20$ & $\begin{array}{l}\text { Riskleri düşürmek için gerekli faaliyetler kisa zamanda (birkaç hafta içinde) başlatılmalıdır. Risk, } \\
\text { faaliyetin durdurulmasını gerektirecek kadar büyük değilse çalışmalar kontrollü olarak, yetkili } \\
\text { kişilerce yürütülmelidir. }\end{array}$ \\
\hline Tolere Edilemez & 25 & $\begin{array}{l}\text { Risk, kabul edilebilir seviyeye düşürülünceye kadar iş başlatılmamalı, devam eden faaliyet varsa } \\
\text { hemen durdurulmalıdır. Geç̧ekleştirilen faaliyetlere rağmen risk düşmüyorsa, faaliyet } \\
\text { engellenmelidir. }\end{array}$
\end{tabular}




\section{Bulgular ve Tartışma}

\subsection{Eğitim ve bilgilendirme}

Eğitim ve bilgilendirme kaynağındaki tehlike ve risklerin değerlendirilmesine ilişkin bilgiler Çizelge 3' de verilmiştir.

Çizelge 3. Eğitim ve bilgilendirme faktöründeki tehlike ve risklerin değerlendirilmesi

\begin{tabular}{|c|c|c|c|c|c|c|c|c|c|}
\hline \multirow{3}{*}{$\begin{array}{c}\text { Tehlike } \\
\text { Kaynağı }\end{array}$} & \multirow{3}{*}{ Tehlike } & \multirow{3}{*}{ Risk } & \multirow{3}{*}{$\begin{array}{l}\text { Mevcut } \\
\text { Durum }\end{array}$} & \multicolumn{6}{|c|}{ Risklerin Değerlendirilmesi } \\
\hline & & & & \multicolumn{2}{|c|}{ Olasılık (O) } & \multicolumn{2}{|c|}{ Şiddet (Ş) } & \multicolumn{2}{|c|}{ Risk Skoru $(\mathbf{O} * \mathbf{S})$} \\
\hline & & & & Değeri & Seviyesi & Değeri & Seviyesi & Değeri & Seviyesi \\
\hline \multirow{5}{*}{ 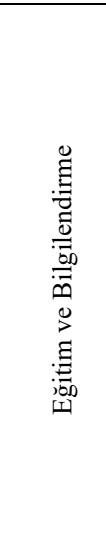 } & $\begin{array}{c}\text { Uyarı ve ikaz } \\
\text { levhalarının olmaması }\end{array}$ & $\begin{array}{l}\text { Ölüm, yaralanma, } \\
\text { maddi hasar }\end{array}$ & $\begin{array}{c}\text { Uyarı ve ikaz } \\
\text { levhaları } \\
\text { yetersizdir. }\end{array}$ & 3 & Orta & 5 & Çok Ciddi & 15 & Ciddi \\
\hline & $\begin{array}{c}\text { Çalışanlara, işe } \\
\text { başlamadan önce İSG } \\
\text { eğitimlerinin } \\
\text { verilmemesi }\end{array}$ & \begin{tabular}{|c|} 
Ölüm, sakat \\
kalma, yaralanma, \\
maddi hasar, \\
yangın \\
\end{tabular} & \begin{tabular}{|c|}
$\begin{array}{c}\text { Sözkonusu } \\
\text { eğitimler } \\
\text { verilmektedir. }\end{array}$ \\
\end{tabular} & 1 & $\begin{array}{l}\text { Çok } \\
\text { Küçük }\end{array}$ & 5 & Çok Ciddi & 5 & Düşük \\
\hline & $\begin{array}{c}\text { Çalışanlara, periyodik } \\
\text { olarak İSG eğitimlerinin } \\
\text { verilmemesi }\end{array}$ & \begin{tabular}{|c|} 
Ölüm, sakat \\
kalma, yaralanma, \\
maddi hasar, \\
yangın
\end{tabular} & $\begin{array}{c}\text { Sözkonusu } \\
\text { eğitimler } \\
\text { verilmektedir. }\end{array}$ & 1 & $\begin{array}{l}\text { Çok } \\
\text { Küçük }\end{array}$ & 5 & Çok Ciddi & 5 & Düşük \\
\hline & $\begin{array}{c}\text { İş kazası veya meslek } \\
\text { hastalığı geçirenlere, } \\
\text { ilave İSG eğitimlerinin } \\
\text { verilmemesi }\end{array}$ & $\begin{array}{c}\text { Ölüm, sakat } \\
\text { kalma, yaralanma, } \\
\text { maddi hasar }\end{array}$ & $\begin{array}{c}\text { Sözkonusu } \\
\text { eğitimler } \\
\text { verilmektedir. }\end{array}$ & 1 & $\begin{array}{l}\text { Çok } \\
\text { Küçük }\end{array}$ & 5 & Çok Ciddi & 5 & Düşük \\
\hline & \multicolumn{3}{|c|}{ ORTALAMA } & 1.500 & Küçük & 5 & $\begin{array}{l}\text { Çok } \\
\text { Ciddi }\end{array}$ & 7.500 & Orta \\
\hline
\end{tabular}

Çizelge 3'de göre ilgili işyerindeki, eğitim ve bilgilendirme faktöründeki tehlikelerin olasılık değeri en yüksek; uyarı ve ikaz levhalarının olmaması, en düşük; çalışanlara, işe başlamadan önce İSG eğitimlerinin verilmemesi, çalışanlara, periyodik olarak İSG eğitimlerinin verilmemesi ve iş kazası veya meslek hastalığı geçirenlere, ilave İSG eğitimlerinin verilmemesi olduğu ve işyerinde tespit edilen tüm tehlikelerin olasılık değerlerinin ortalamasının (1.500) olduğu tespit edilmiştir.Şiddet değerinin, tüm tehlikelerde en yüksek seviyede olduğu ve bunların ortalama değerlerinin de(5) olduğu tespit edilmiştir. Risk skoru değeri en yüksek; uyarı ve ikaz levhalarının olmaması, en düşük; çalışanlara, işe başlamadan önce İSG eğitimlerinin verilmemesi, çalışanlara, periyodik olarak İSG eğitimlerinin verilmemesi ve iş kazası veya meslek hastalığı geçirenlere, ilave İSG eğitimlerinin verilmemesi olduğu ve işyerinde tespit edilen tüm tehlikelere ait risk skorlarının ortalamasının (7.500)olduğu tespit edilmiştir.

Seyhan (2009), Ankara ilindeki ağaç işleri sektöründe faaliyet gösteren orta ve büyük ölçekli işletmelerin İSG açısından mevcut durumlarının ortaya konulması ve bu konu kapsamındaki sorunlara yönelik çözüm önerileri getirmek amacıyla gerçekleştirdiği çalışma kapsamında; 29 farklı işyerine İSG hizmetleri; eğitim, bilinç ve yeterlilik; tehlike belirleme; risk değerlendirme ve risk kontrolü için planlama konularını kapsayan anket uygulamıştır. Bunun sonucunda, İSG ile ilgili yerleşik bireğitim prosedürü uygulayan işyeri sayısının azınlıkta kaldığını (5) belirlemiştir.

\section{2. Çalışan sağlığı}

Çalışan sağlığı kaynağındaki tehlike ve risklerin değerlendirilmesine ilişkin bilgiler Çizelge 4'de verilmiştir. 
Çizelge 4. Çalışan sağlı̆̆ kaynağındaki tehlike ve risklerin değerlendirilmesi

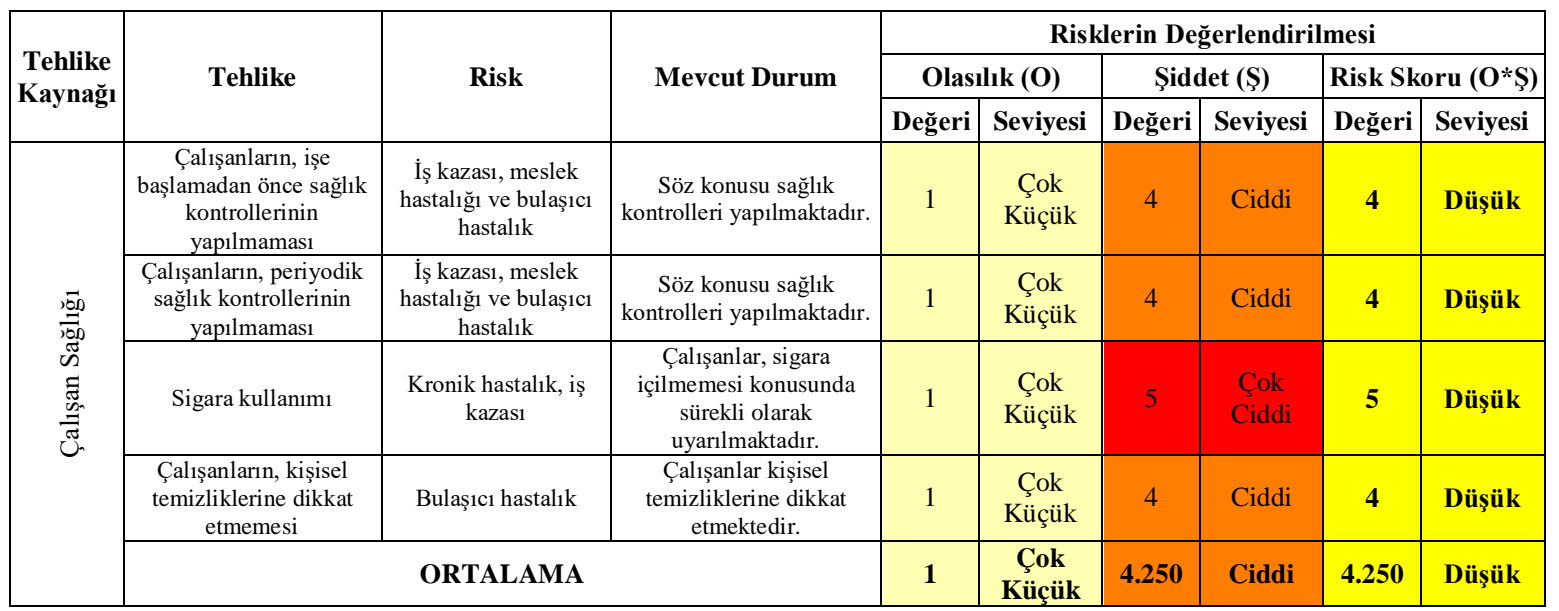

Çizelge 4'de göre ilgili işyerindeki, çalışan sağlığı kaynağındaki tehlikelerin olasılık değerinin, tüm tehlikelerde en düşük seviyede olduğu ve bunların ortalama değerlerinin de (1) olduğu tespit edilmiştir. Şiddet değeri en yüksek; sigara kullanımında, bunun dışındaki tüm tehlikelerin şiddet düzeylerinin de olduğu ve işyerinde tespit edilen tüm tehlikelere ait şiddet değerlerinin ortalamasının (4.250) olduğu tespit edilmiştir. Risk skoru en yüksek; sigara kullanımında, bunun dışındaki tüm tehlikelerin risk skoru düzeylerinin de olduğu ve işyerinde tespit edilen tüm tehlikelere ait şiddet değerlerinin ortalamasının (4.250) olduğu tespit edilmiştir.

Yılmaz (2012), küçük ve orta ölçekli işletmeler (KOBİ) ile büyük boy işletmeleri (BBİ) karşılaştırarak mobilya sektöründe meydana gelen iş kazalarının analizlerini yaparak iş kazalarına ilişkin durumu, karşılaşılan sorunları, çözüm önerilerini ve çalışanların görüşlerini belirlemek amacı ile gerçekleştirdiği çalışmasında; 98'i büyük boy olmak üzere, toplam 198 çalışana anket uygulamıştır. Bunun sonucunda, iş kazalarına karşı alınabilecek sosyal faktörlere ilişkin görüş ve önerilerinde; KOBİ çalışanlarının \%17.8'i, BBİ çalışanlarının ise 15.2'si alkol, sigara ve kötü alışkanlıklara karşı önlem alınmasıgerektiğini belirtmişlerdir.

\subsection{Acil durumlar}

Acil durumlar kaynağındaki tehlike ve risklerin değerlendirilmesine ilişkin bilgiler Çizelge 5'te verilmiştir.

Çizelge 5. Acil durumlar kaynağındaki tehlike ve risklerin değerlendirilmesi

\begin{tabular}{|c|c|c|c|c|c|c|c|c|c|}
\hline \multirow{3}{*}{$\begin{array}{l}\text { Tehlike } \\
\text { Kaynağı }\end{array}$} & \multirow{3}{*}{ Tehlike } & \multirow{3}{*}{ Risk } & \multirow{3}{*}{$\begin{array}{l}\text { Mevcut } \\
\text { Durum }\end{array}$} & \multicolumn{6}{|c|}{ Risklerin Değerlendirilmesi } \\
\hline & & & & \multicolumn{2}{|c|}{ Olasılık (O) } & \multicolumn{2}{|c|}{ Şiddet (Ş) } & \multicolumn{2}{|c|}{ Risk Skoru $(\mathbf{O * S ̧})$} \\
\hline & & & & Değeri & Seviyesi & Değeri & Seviyesi & Değeri & Seviyesi \\
\hline \multirow{5}{*}{ 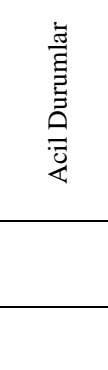 } & $\begin{array}{c}\text { Acil durum planının } \\
\text { olmaması }\end{array}$ & $\begin{array}{l}\text { İş kazası, uzuv kaybı, } \\
\text { yaralanma ve ölüm }\end{array}$ & Acil durum planı vardır. & 2 & Küçük & 5 & Çok Ciddi & 10 & Orta \\
\hline & \begin{tabular}{|c|} 
Acil durum \\
ekiplerinin olmaması
\end{tabular} & \begin{tabular}{|c} 
İş kazası, uzuv kaybı, \\
yaralanma ve ölüm
\end{tabular} & $\begin{array}{c}\text { Acil durum ekipleri } \\
\text { vardır. }\end{array}$ & 2 & Küçük & 5 & Çok Ciddi & 10 & Orta \\
\hline & \begin{tabular}{|c|} 
Acil durum \\
tatbikatlarının \\
yapılmaması \\
\end{tabular} & $\begin{array}{l}\text { İș kazası, uzuv kaybı, } \\
\text { yaralanma ve ölüm }\end{array}$ & $\begin{array}{l}\text { Acil durum tatbikatları } \\
\text { yapılmamaktadır. }\end{array}$ & 4 & Yüksek & 5 & Çok Ciddi & 20 & Ciddi \\
\hline & $\begin{array}{c}\text { Acil durum } \\
\text { toplanma yerinin } \\
\text { olmaması }\end{array}$ & $\begin{array}{l}\text { İş kazası, uzuv kaybı, } \\
\text { yaralanma ve ölüm }\end{array}$ & $\begin{array}{l}\text { Acil durum toplanma yeri } \\
\text { yoktur. }\end{array}$ & 4 & Yüksek & 5 & Çok Ciddi & 20 & Ciddi \\
\hline & \multicolumn{3}{|c|}{ ORTALAMA } & 3 & Orta & 5 & $\begin{array}{l}\text { Çok } \\
\text { Ciddi }\end{array}$ & 15 & Ciddi \\
\hline
\end{tabular}


Çizelge 5'e göre ilgili işyerindeki, acil durumlar kaynağındaki tehlikelerin olasılık değerinin, en yüksek; acil durum tatbikatlarının yapılmaması ve acil durum toplanma yerinin olmaması, en düşük; acil durum planının olmaması ve acil durum ekiplerinin olmaması olduğu ve bunların ortalama değerlerinin de (3) olduğu tespit edilmiştir. Şiddet değerinin, tüm tehlikelerde çok ciddi seviyede olduğu ve bunların ortalama değerlerinin de (5) olduğu tespit edilmiştir. Risk skoru değerinin, en yüksek; acil durum tatbikatlarının yapılmaması ve acil durum toplanma yerinin olmaması, en düşük; acil durum planının olmaması ve acil durum ekiplerinin olmaması olduğu ve bunların ortalama değerlerinin de (15) olduğu tespit edilmiştir.

6331 sayılı İSG Kanununun 11. Maddesine göre, işveren;

- Çalışma ortamı, kullanılan maddeler, iş ekipmanı ile çevre şartlarını dikkate alarak meydana gelebilecek acil durumları önceden değerlendirerek, çalışanları ve çalışma çevresini etkilemesi mümkün ve muhtemel acil durumları belirlemekle; bunların olumsuz etkilerini önleyici ve sinırlandırıcı tedbirlerini almakla,

- Acil durumların olumsuz etkilerinden korunmak üzere gerekli ölçüm ve değerlendirmeleri yapmakla ve bunlara ilişkin acil durum planlarını hazırlamakla,

- Acil durumlarla mücadele için işyerinin büyüklüğü ve taşıdığı özel tehlikeler, yapılan işin niteliği, çalışan sayısı ile işyerinde bulunan diğer kişileri dikkate alarak; önleme, koruma, tahliye, yangınla mücadele, ilk yardım vb. konularda uygun donanıma sahip ve bu konularda eğitimli yeterli sayıda kişiyi görevlendirip; bunların araç ve gereçlerinitemin ederek eğitim ve tatbikatları yaptırmakla ve ekiplerin her zaman hazır bulunmalarını sağlamakla yükümlüdür $\left[\mathrm{ÇSGB}_{1}, 2012\right]$.

\subsection{Yangin}

Yangın kaynağındaki tehlike ve risklerin değerlendirilmesine ilişkin bilgiler Çizelge 6'de verilmiştir.

Çizelge 6. Yangın kaynağındaki tehlike ve risklerin değerlendirilmesi

\begin{tabular}{|c|c|c|c|c|c|c|c|c|c|}
\hline \multirow{3}{*}{$\begin{array}{c}\text { Tehlike } \\
\text { Kaynağı }\end{array}$} & \multirow{3}{*}{ Tehlike } & \multirow{3}{*}{ Risk } & \multirow{3}{*}{ Mevcut Durum } & \multicolumn{6}{|c|}{ Risklerin Değerlendirilmesi } \\
\hline & & & & \multicolumn{2}{|c|}{ Olasılık (O) } & \multicolumn{2}{|c|}{ Şiddet (Ş) } & \multicolumn{2}{|c|}{ Risk Skoru $(\mathbf{O} * \mathbf{S})$} \\
\hline & & & & Değeri & Seviyesi & Değeri & Seviyesi & Değeri & Seviyesi \\
\hline \multirow{4}{*}{ 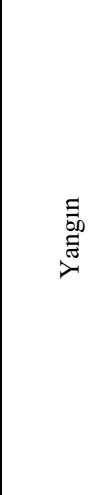 } & $\begin{array}{c}\text { Yeterli miktarda } \\
\text { yangın söndürme } \\
\text { ekipmanının } \\
\text { olmaması }\end{array}$ & $\begin{array}{c}\text { Ölüm, sakat } \\
\text { kalma, yaralanma, } \\
\text { maddi hasar, } \\
\text { yangın } \\
\end{array}$ & $\begin{array}{l}\text { Yeterli miktarda } \\
\text { yangın söndürme } \\
\text { ekipmanı yoktur. }\end{array}$ & 5 & $\begin{array}{c}\text { Çok } \\
\text { Yüksek }\end{array}$ & 5 & $\begin{array}{l}\text { Çok } \\
\text { Ciddi }\end{array}$ & 25 & $\begin{array}{c}\text { Tolere } \\
\text { Edilemez }\end{array}$ \\
\hline & $\begin{array}{c}\text { Yangın dedektörü } \\
\text { ve alarmının } \\
\text { olmaması }\end{array}$ & $\begin{array}{c}\text { Ölüm, sakat } \\
\text { kalma, yaralanma, } \\
\text { maddi hasar, } \\
\text { yangın }\end{array}$ & $\begin{array}{l}\text { Yangin dedektörü ve } \\
\text { alarmı yoktur. }\end{array}$ & 4 & Yüksek & 5 & $\begin{array}{l}\text { Çok } \\
\text { Ciddi }\end{array}$ & 20 & Ciddi \\
\hline & $\begin{array}{c}\text { Yangın söndürme } \\
\text { sistemlerinin kolay } \\
\text { ulaşılabilir } \\
\text { durumda olmaması }\end{array}$ & $\begin{array}{c}\text { Ölüm, sakat } \\
\text { kalma, yaralanma, } \\
\text { maddi hasar, } \\
\text { yangın }\end{array}$ & $\begin{array}{l}\text { Yangın söndürme } \\
\text { cihazları görünür ve } \\
\text { kolay erişilebilir } \\
\text { yerde değildir. }\end{array}$ & 4 & Yüksek & 5 & $\begin{array}{l}\text { Çok } \\
\text { Ciddi }\end{array}$ & 20 & Ciddi \\
\hline & \multicolumn{3}{|c|}{ ORTALAMA } & 4.333 & Yüksek & 5 & $\begin{array}{l}\text { Çok } \\
\text { Ciddi }\end{array}$ & 21.667 & \begin{tabular}{|c|} 
Tolere \\
Edilemez
\end{tabular} \\
\hline
\end{tabular}

Çizelge 6'e göre ilgili işyerindeki, yangın kaynağındaki tehlikelerin olasılık değerinin, en yükssek; yeterli miktarda yangın söndürme ekipmanının olmaması, en düşük; yangın dedektörü ve alarmının olmaması ve yangın söndürme sistemlerinin kolay ulaşılabilir durumda olmaması ve bunların ortalama değerlerinin de (4.333) olduğu tespit edilmiştir. Şiddet değerinin, tüm tehlikelerde çok ciddi seviyede olduğu ve bunların ortalama 
değerlerinin (5) olduğu tespit edilmiştir. Risk skoru değerinin, en yüksek; yeterli miktarda yangın söndürme ekipmanının olmaması, en düşük; yangın dedektörü ve alarmının olmaması ve yangın söndürme sistemlerinin kolay ulaşılabilir durumda olmaması olduğu ve bunların ortalama değerlerinin de (21.667) olduğu tespit edilmiştir.

Kalkan (2013), yangın riski oluşturan birçok etmeni tespit etmiş olduğu çalışmasında, yangın söndürme ekipmanlarının yeterli ve düzenli olmadığını vurgulamıştır.

\subsection{Ortam faktörleri}

Ortam faktörleri kaynağındaki tehlike ve risklerin değerlendirilmesine ilişkin bilgiler Çizelge 7'te verilmiştir.

Çizelge 7. Ortam faktörleri kaynağındaki tehlike ve risklerin değerlendirilmesi

\begin{tabular}{|c|c|c|c|c|c|c|c|c|c|}
\hline \multirow{3}{*}{$\begin{array}{c}\text { Tehlike } \\
\text { Kaynağı }\end{array}$} & \multirow{3}{*}{ Tehlike } & \multirow{3}{*}{ Risk } & \multirow{3}{*}{ Mevcut Durum } & \multicolumn{6}{|c|}{ Risklerin Değerlendirilmesi } \\
\hline & & & & \multicolumn{2}{|c|}{ Olasılık (O) } & \multicolumn{2}{|c|}{ Şiddet (Ş) } & \multicolumn{2}{|c|}{ Risk Skoru $(\mathbf{O} * \mathbf{S})$} \\
\hline & & & & Değeri & Seviyesi & Değeri & Seviyesi & Değeri & Seviyesi \\
\hline \multirow{13}{*}{ 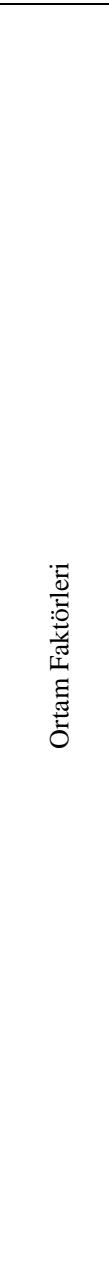 } & $\begin{array}{c}\text { Yetersiz } \\
\text { havalandırma }\end{array}$ & Bulaşıcı hastalık & $\begin{array}{c}\text { Havalandırma } \\
\text { sistemi yoktur. }\end{array}$ & 3 & Orta & 4 & Ciddi & 12 & Orta \\
\hline & $\begin{array}{c}\text { Yetersiz } \\
\text { aydınlatma }\end{array}$ & İş kazası & $\begin{array}{l}\text { Aydınlatma sistemi } \\
\text { çalışma ortamına } \\
\text { elverişlidir. }\end{array}$ & 2 & Küçük & 3 & Orta & 6 & Düşük \\
\hline & $\begin{array}{c}\text { Yedek aydınlatma } \\
\text { sisteminin } \\
\text { olmaması }\end{array}$ & İş kazası & $\begin{array}{l}\text { Yedek aydınlatma } \\
\text { sistemi vardır. }\end{array}$ & 2 & Küçük & 3 & Orta & 6 & Düşük \\
\hline & $\begin{array}{l}\text { Ortam sıcaklığının } \\
\text { yeterli ve dengeli } \\
\text { olmaması }\end{array}$ & $\begin{array}{c}\text { İş kazası ve } \\
\text { bulaşıcı hastalık }\end{array}$ & $\begin{array}{l}\text { Yeterli ve dengeli } \\
\text { 1sitma } \\
\text { yapılmamaktadır. }\end{array}$ & 4 & Yüksek & 4 & Ciddi & 16 & Ciddi \\
\hline & $\begin{array}{l}\text { Isıtma sisteminin, } \\
\text { çalışma } \\
\text { güvenliğine uygun } \\
\text { olmaması }\end{array}$ & \begin{tabular}{|c|} 
İş kazası, \\
yangın, patlama, \\
yaralanma ve \\
ölüm
\end{tabular} & $\begin{array}{l}\text { Soba ile } 1 \text { sitma } \\
\text { yapılmaktadır. }\end{array}$ & 4 & Yüksek & 5 & $\begin{array}{l}\text { Çok } \\
\text { Ciddi }\end{array}$ & 20 & Ciddi \\
\hline & $\begin{array}{c}\text { Gürültü } \\
\text { maruziyeti }\end{array}$ & $\begin{array}{c}\text { İş kazası ve } \\
\text { meslek hastalığ1 }\end{array}$ & $\begin{array}{c}\text { Çalışanlar kulak } \\
\text { koruyucusu } \\
\text { kullanmamaktadır. }\end{array}$ & 4 & Yüksek & 4 & Ciddi & 16 & Ciddi \\
\hline & $\begin{array}{c}\text { Gürültü } \\
\text { ölçümlerinin } \\
\text { yapılmaması }\end{array}$ & $\begin{array}{c}\text { İş kazası ve } \\
\text { meslek hastalığ }\end{array}$ & $\begin{array}{l}\text { Periyodik olarak } \\
\text { gürülttü düzeyi } \\
\text { ölçülmektedir. }\end{array}$ & 2 & Küçük & 4 & Ciddi & 8 & Orta \\
\hline & $\begin{array}{c}\text { Makinelerde, toz } \\
\text { emicilerin } \\
\text { bulunmaması }\end{array}$ & $\begin{array}{c}\text { İş kazası ve } \\
\text { meslek hastalığ }\end{array}$ & $\begin{array}{c}\text { Makinelere toz emici } \\
\text { sistem tak1lidir. }\end{array}$ & 2 & Küçük & 4 & Ciddi & 8 & Orta \\
\hline & $\begin{array}{l}\text { Toz ölçümlerinin } \\
\text { yapılmaması }\end{array}$ & $\begin{array}{c}\text { İş kazası ve } \\
\text { meslek hastalığı }\end{array}$ & $\begin{array}{c}\text { Periyodik olarak toz } \\
\text { düzeyi } \\
\text { ölçülmemektedir. }\end{array}$ & 4 & Yüksek & 4 & Ciddi & 16 & Ciddi \\
\hline & Toz maruziyeti & $\begin{array}{c}\text { İş kazası ve } \\
\text { meslek hastalığı }\end{array}$ & $\begin{array}{l}\text { Çalışanlar maske } \\
\text { kullanmamaktadır. }\end{array}$ & 4 & Yüksek & 4 & Ciddi & 16 & Ciddi \\
\hline & $\begin{array}{c}\text { Titreşim } \\
\text { ölçümlerinin } \\
\text { yapılmaması }\end{array}$ & $\begin{array}{c}\text { İş kazası ve } \\
\text { meslek hastalığı }\end{array}$ & $\begin{array}{l}\text { Periyodik olarak } \\
\text { titreşim maruziyet } \\
\text { düzeyleri } \\
\text { ölçülmemektedir. }\end{array}$ & 4 & Yüksek & 4 & Ciddi & 16 & Ciddi \\
\hline & $\begin{array}{l}\text { Titreşim } \\
\text { maruziyeti }\end{array}$ & $\begin{array}{c}\text { İş kazası ve } \\
\text { meslek hastalığı }\end{array}$ & $\begin{array}{l}\text { Çalışanlara, } \\
\text { titreşimden } \\
\text { korunmaları için } \\
\text { uygun KKD } \\
\text { verilmemiştir. }\end{array}$ & 4 & Yüksek & 4 & Ciddi & 16 & Ciddi \\
\hline & & ORTALAMA & & 3.25 & Orta & 3.917 & Ciddi & 12.729 & Orta \\
\hline
\end{tabular}

Çizelge 7'e göre ilgili işyerindeki, ortam faktörleri kaynağındaki tehlikelerin olasılık değerinin, en yüksek; ortam sicaklığının yeterli ve dengeli olmaması, 1sıtma sisteminin, çalışma güvenliğine uygun olmaması, gürültü maruziyeti, toz ölçümlerinin yapılmaması, toz maruziyeti, titreşim ölçümlerinin yapılmaması ve titreşim maruziyeti, en düşük; yetersiz aydınlatma, yedek aydınlatma sisteminin olmaması, gürültü ölçümlerinin yapılmaması ve 
makinelerde, toz emicilerin bulunmaması olduğu ve bunların ortalama değerlerinin de (3.25) olduğu tespit edilmiştir.Şiddet değerinin, en yüksek; 1sıtma sisteminin, çalışma güvenliğine uygun olmaması, bunun dışındaki tüm tehlikelerde ciddi seviyede olduğu ve bunların ortalama değerlerinin de (3.917) olduğu tespit edilmiştir.Risk skoru değerinin, en yüksek; 1sıtma sisteminin, çalışma güvenliğine uygun olmaması, en düşük; yetersiz aydınlatma ve yedek aydınlatma sisteminin olmaması olduğu ve bunların ortalama değerlerinin de (12.729) olduğu tespit edilmiştir.

Sönmez ve ark. (2009), Ankara'da mobilya sektöründe faaliyet gösteren küçük ve orta büyüklükteki işletmelerdeki ortam faktörlerini incelemiş; bu işyerlerinde aydınlatma düzeyinin, ısıtma sisteminin, hava şartlarının, temizliğin yetersiz olduğunu ve çalışma esnasında gürültüye maruz kalındığınıbelirtmişlerdir.

\subsection{Psiko-sosyal risk etmenleri}

Psiko-sosyal risk etmenleri kaynağındaki tehlike ve risklerin değerlendirilmesine ilişkin bilgiler Çizelge 8'da verilmiştir.

Çizelge 8. Psiko-sosyal risk etmenleri kaynağındaki tehlike ve risklerin değerlendirilmesi

\begin{tabular}{|c|c|c|c|c|c|c|c|c|c|}
\hline \multirow{3}{*}{$\begin{array}{l}\text { Tehlike } \\
\text { Kaynağı }\end{array}$} & \multirow{3}{*}{ Tehlike } & \multirow{3}{*}{ Risk } & \multirow{3}{*}{ Mevcut Durum } & \multicolumn{6}{|c|}{ Risklerin Değerlendirilmesi } \\
\hline & & & & \multicolumn{2}{|c|}{ Olasilık (O) } & \multicolumn{2}{|c|}{ Şiddet (Ş) } & \multicolumn{2}{|c|}{ Risk Skoru $(\mathbf{O} *$ Ş) } \\
\hline & & & & Değeri & Seviyesi & Değeri & Seviyesi & Değeri & Seviyesi \\
\hline \multirow{5}{*}{ 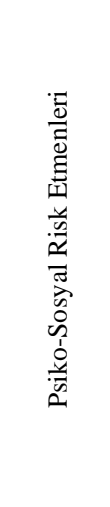 } & $\begin{array}{l}\text { Çalışma saatlerinin, } \\
\text { düzensiz olması }\end{array}$ & $\begin{array}{l}\text { İş kazass, } \\
\text { yaralanma }\end{array}$ & $\begin{array}{l}\text { Çalışma saatleri, ilgili } \\
\text { mevzuata uygundur. }\end{array}$ & 1 & $\begin{array}{l}\text { Çok } \\
\text { Küçük }\end{array}$ & 3 & Orta & 3 & Düşük \\
\hline & $\begin{array}{l}\text { Dinlenme aralarının } \\
\text { yetersiz olması }\end{array}$ & $\begin{array}{l}\text { İş kazası, } \\
\text { yaralanma }\end{array}$ & $\begin{array}{l}\text { Dinlenme araları, yeterli } \\
\text { düzeydedir. }\end{array}$ & 1 & $\begin{array}{c}\text { Çok } \\
\text { Küçük }\end{array}$ & 3 & Orta & 3 & Düşük \\
\hline & $\begin{array}{l}\text { Uzun süren fazla } \\
\text { mesailer }\end{array}$ & $\begin{array}{l}\text { İş kazası, } \\
\text { yaralanma }\end{array}$ & $\begin{array}{l}\text { İşlerin yetiştirilebilmesi için, } \\
\text { bazen mesailer uzun } \\
\text { sürmektedir. }\end{array}$ & 3 & Orta & 3 & Orta & 9 & Orta \\
\hline & $\begin{array}{l}\text { Çalışanların, taciz } \\
\text { ve şiddete maruz } \\
\text { kalması }\end{array}$ & İş kazası & Gerekli önlemler alınmıştır. & 2 & Küçük & 3 & Orta & 6 & Düşük \\
\hline & \multicolumn{3}{|c|}{ ORTALAMA } & 1.75 & Küçük & 3 & Orta & 5.25 & Düşük \\
\hline
\end{tabular}

Çizelge 8'ya göre ilgili işyerindeki, psiko-sosyal risk etmenleri kaynağındaki tehlikelerin olasılık değerinin, en yüksek; uzun süren fazla mesailerde, en düşük; çalışma saatlerinin, düzensiz olması, dinlenme aralarının yetersiz olmas1 ve bunların ortalama değerlerinin de (1.75) olduğu tespit edilmiştir.Şiddet değerinin, tüm tehlikelerde orta seviyede olduğu ve bunların ortalama değerlerinin (3) olduğu tespit edilmiştir.Risk skoru değerinin, en yüksek; uzun süren fazla mesailerde, en düşük; çalışma saatlerinin, düzensiz olması, dinlenme aralarının yetersiz olması olduğu ve bunların ortalama değerlerinin de (5.25) olduğu tespit edilmiştir.

Semerci (2014), Kızılçam kerestenin işlenmesi esnasında, çalışanlar üzerinde oluşabilecek sağlık sorunlarının tespit etmek amacıyla yapmış olduğu çalışmasında; Akdeniz Bölgesinde yer alan ve safi kızılçam işleyen kereste işletmelerinde çalışanlara anket uygulamıştır.Bunun sonucunda; çalışanların \%23'ü mesai saatlerinin uzun olduğunu, \%9.68'i molaların kısa olduğunu, \%9.23'ü ücretlerin ve çalışma ortamının iyileştirilmesini istediklerini belirtmiştir. 


\subsection{Bakım ve onarım}

Bakım ve onarım kaynağındaki tehlike ve risklerin değerlendirilmesine ilişkin bilgiler Çizelge 9'de verilmiştir.

Çizelge 9. Bakım ve onarım kaynağındaki tehlike ve risklerin değerlendirilmesi

\begin{tabular}{|c|c|c|c|c|c|c|c|c|c|}
\hline \multirow{3}{*}{$\begin{array}{l}\text { Tehlike } \\
\text { Kaynağı }\end{array}$} & \multirow{3}{*}{ Tehlike } & \multirow{3}{*}{ Risk } & \multirow{3}{*}{ Mevcut Durum } & \multicolumn{6}{|c|}{ Risklerin Değerlendirilmesi } \\
\hline & & & & \multicolumn{2}{|c|}{ Olasilık (O) } & \multicolumn{2}{|c|}{ Şiddet (Ş) } & \multicolumn{2}{|c|}{ Risk Skoru $(\mathrm{O} *$ Ş) } \\
\hline & & & & Değeri & Seviyesi & Değeri & Seviyesi & Değeri & Seviyesi \\
\hline \multirow{3}{*}{$\begin{array}{l}\text { Bakım ve } \\
\text { Onarım }\end{array}$} & $\begin{array}{l}\text { Bakım ve kontrol } \\
\text { işlemlerini yetkisiz } \\
\text { kişilerin yapması }\end{array}$ & $\begin{array}{l}\text { İş kazası, } \\
\text { uzuv kaybı, } \\
\text { yaralanma } \\
\text { ve ölüm }\end{array}$ & $\begin{array}{l}\text { Bakım ve kontrol } \\
\text { işlemlerini ilgili bilgi } \\
\text { ve beceriye sahip } \\
\text { kişiler yapmaktadır. }\end{array}$ & 2 & Küçük & 5 & Çok Ciddi & 10 & Orta \\
\hline & $\begin{array}{c}\text { Bakım ve kontrol } \\
\text { işlemleri için çalışma } \\
\text { talimatlarının olmaması }\end{array}$ & $\begin{array}{l}\text { İş kazası, } \\
\text { uzuv kayb1, } \\
\text { yaralanma } \\
\text { ve ölüm }\end{array}$ & $\begin{array}{l}\text { Bakım ve kontrol } \\
\text { işlemleri için çalışma } \\
\text { talimatları yoktur. }\end{array}$ & 4 & Yüksek & 5 & Çok Ciddi & 20 & Ciddi \\
\hline & \multicolumn{3}{|c|}{ ORTALAMA } & 3 & Orta & 5 & $\begin{array}{l}\text { Çok } \\
\text { Ciddi }\end{array}$ & 15 & Ciddi \\
\hline
\end{tabular}

Çizelge 9'ye göre ilgili işyerindeki, elektrik pano ve tesisatı kaynağındaki tehlikelerin olasılık değerinin, en yüksek; bakım ve kontrol işlemleri için çalışma talimatlarının olmaması, en düşük; bakım ve kontrol işlemlerini yetkisiz kişilerin yapması olduğu ve bunların ortalama değerlerinin de (3) olduğu tespit edilmiştir. Şiddet değerinin, tüm tehlikelerde çok ciddi seviyede olduğu ve bunların ortalama değerlerinin de (5) olduğu tespit edilmiştir. Risk skoru değerinin, en yüksek; bakım ve kontrol işlemleri için çalışma talimatlarının olmaması, en düşük; bakım ve kontrol işlemlerini yetkisiz kişilerin yapması olduğu ve bunların ortalama değerlerinin de (15) olduğu tespit edilmiştir.

\subsection{Malzeme depolama alanı}

Malzeme depolama alanı kaynağındaki tehlike ve risklerin değerlendirilmesine ilişkin bilgiler Çizelge 10'de verilmiştir.

Çizelge 10. Malzeme depolama alanı kaynağındaki tehlike ve risklerin değerlendirilmesi

\begin{tabular}{|c|c|c|c|c|c|c|c|c|c|}
\hline \multirow{3}{*}{$\begin{array}{l}\text { Tehlike } \\
\text { Kaynağı }\end{array}$} & \multirow{3}{*}{ Tehlike } & \multirow{3}{*}{ Risk } & \multirow{3}{*}{ Mevcut Durum } & \multicolumn{6}{|c|}{ Risklerin Değerlendirilmesi } \\
\hline & & & & \multicolumn{2}{|c|}{ Olasılık (O) } & \multicolumn{2}{|c|}{ Şiddet (Ş) } & \multicolumn{2}{|c|}{ Risk Skoru $(\mathbf{O} * \mathbf{S})$} \\
\hline & & & & Değeri & Seviyesi & Değeri & Seviyesi & Değeri & Seviyesi \\
\hline \multirow{8}{*}{ 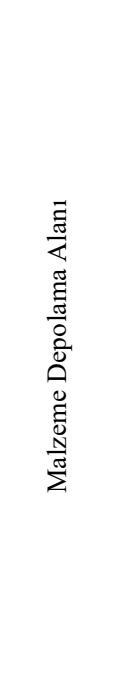 } & $\begin{array}{l}\text { Temizlik ve düzenin, } \\
\text { yeterli seviyede olmaması }\end{array}$ & İş kazası, yaralanma & Yeterli değildir & 3 & Orta & 4 & Ciddi & 12 & Orta \\
\hline & $\begin{array}{c}\text { Malzemelerin, üst üste } \\
\text { yığılması }\end{array}$ & İş kazası, yaralanma & $\begin{array}{l}\text { Kısmen yığılma } \\
\text { vardır. }\end{array}$ & 3 & Orta & 4 & Ciddi & 12 & Orta \\
\hline & $\begin{array}{c}\text { Malzemelerin, çalışanları } \\
\text { engelleyecek biçimde } \\
\text { durması }\end{array}$ & İş kazası, yaralanma & $\begin{array}{c}\text { K1smen } \\
\text { engellemektedir. }\end{array}$ & 3 & Orta & 4 & Ciddi & 12 & Orta \\
\hline & $\begin{array}{c}\text { Yanıcı ve patlayıcı } \\
\text { maddelerin ayrı olarak } \\
\text { depolanmaması }\end{array}$ & $\begin{array}{c}\text { İş kazası, yangın, } \\
\text { patlama, yaralanma } \\
\text { ve ölüm }\end{array}$ & 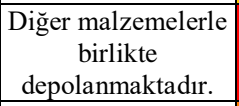 & 5 & $\begin{array}{l}\text { Çok } \\
\text { Yüksek }\end{array}$ & 5 & $\begin{array}{l}\text { Çok } \\
\text { Ciddi }\end{array}$ & 25 & $\begin{array}{c}\text { Tolere } \\
\text { Edilemez }\end{array}$ \\
\hline & $\begin{array}{l}\text { Kimyasal, yanıcı ve } \\
\text { patlayıcı maddelerin } \\
\text { malzeme güvenlik bilgi } \\
\text { formlarının olmaması }\end{array}$ & $\begin{array}{c}\text { İş kazası, yangın, } \\
\text { patlama, yaralanma } \\
\text { ve ölüm }\end{array}$ & $\begin{array}{l}\text { Malzeme güvenlik } \\
\text { bilgi formları } \\
\text { yoktur. }\end{array}$ & 4 & Yüksek & 5 & $\begin{array}{l}\text { Çok } \\
\text { Ciddi }\end{array}$ & 20 & Ciddi \\
\hline & $\begin{array}{c}\text { Yangın söndürücü } \\
\text { olmaması }\end{array}$ & $\begin{array}{c}\text { İş kazası, yaralanma } \\
\text { ve ölüm }\end{array}$ & $\begin{array}{c}\text { Yangın söndürücü } \\
\text { yoktur. }\end{array}$ & 4 & Yüksek & 5 & $\begin{array}{l}\text { Çok } \\
\text { Ciddi } \\
\end{array}$ & 20 & Ciddi \\
\hline & $\begin{array}{c}\text { Uyarı ve ikaz levhalarının } \\
\text { olmaması }\end{array}$ & $\begin{array}{c}\text { İş kazası, yangın, } \\
\text { patlama, yaralanma } \\
\text { ve ölüm } \\
\end{array}$ & $\begin{array}{l}\text { Uyarı ve ikaz } \\
\text { levhaları yoktur. }\end{array}$ & 3 & Orta & 5 & $\begin{array}{l}\text { Çok } \\
\text { Ciddi }\end{array}$ & 15 & Ciddi \\
\hline & \multicolumn{3}{|c|}{ ORTALAMA } & 3.571 & Yüksek & 4.571 & $\begin{array}{c}\text { Çok } \\
\text { Ciddi }\end{array}$ & 16.327 & Ciddi \\
\hline
\end{tabular}


Çizelge 10.'e göre ilgili işyerindeki, malzeme depolama alanı kaynağındaki tehlikelerin olasılık değerinin, en yüksek; yanıcı ve patlayıcı maddelerin ayrı olarak depolanmaması, en düşük; temizlik ve düzenin, yeterli seviyede olmaması, malzemelerin, üst üste yı̆̆ılması, malzemelerin, çalışanları engelleyecek biçimde durması, uyarı ve ikaz levhalarının olmaması olduğu ve bunların ortalama değerlerinin de (3.571) olduğu tespit edilmiştir. Şiddet değerinin, temizlik ve düzenin, yeterli seviyede olmaması, malzemelerin, üst üste yığılmas1, malzemelerin, çalışanları engelleyecek biçimde durması, bunun dişındaki tüm tehlikelerde çok ciddi seviyede olduğu ve bunların ortalama değerlerinin de (4.571) olduğu tespit edilmiştir. Risk skoru değerinin, en yüksek; yanıcı ve patlayıcı maddelerin ayrı olarak depolanmaması, en düşük; temizlik ve düzenin, yeterli seviyede olmaması, malzemelerin, çalışanları engelleyecek biçimde durması olduğu ve bunların ortalama değerlerinin de (16.327) olduğu tespit edilmiştir.

Pedis (2018), çalışma alanında malzemelerin dağınık şekilde bulunması, kimyasal maddelerin depolanmaması ve kimyasal maddeler için güvenlik bilgi formunun olmaması tehlikelerine ait risk skorunu 12 olarak belirlemiştir.

\subsection{Montaj alanı}

Montaj alanı kaynağındaki tehlike ve risklerin değerlendirilmesine ilişkin bilgiler Çizelge 11'da verilmiştir.

Çizelge 11. Montaj alanı kaynağındaki tehlike ve risklerin değerlendirilmesi

\begin{tabular}{|c|c|c|c|c|c|c|c|c|c|}
\hline \multirow{3}{*}{$\begin{array}{c}\text { Tehlike } \\
\text { Kaynağı }\end{array}$} & \multirow{3}{*}{ Tehlike } & \multirow{3}{*}{ Risk } & \multirow{3}{*}{ Mevcut Durum } & \multicolumn{6}{|c|}{ Risklerin Değerlendirilmesi } \\
\hline & & & & \multicolumn{2}{|c|}{ Olasılık (O) } & \multicolumn{2}{|c|}{ Şiddet (Ş) } & \multicolumn{2}{|c|}{ Risk Skoru $(0 *$ Ş) } \\
\hline & & & & Değeri & Seviyesi & Değeri & Seviyesi & Değeri & Seviyesi \\
\hline \multirow{5}{*}{ 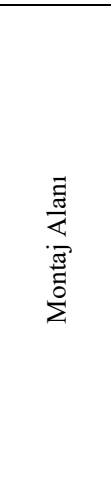 } & $\begin{array}{l}\text { Yangın algılama } \\
\text { sistemi olmaması }\end{array}$ & $\begin{array}{l}\text { İş kazası, yangın, } \\
\text { yaralanma, uzuv } \\
\text { kaybı ve ölüm }\end{array}$ & $\begin{array}{l}\text { Yangin algilama } \\
\text { sistemi yoktur. }\end{array}$ & 4 & Yüksek & 5 & $\begin{array}{c}\text { Çok } \\
\text { Ciddi }\end{array}$ & 20 & Ciddi \\
\hline & $\begin{array}{l}\text { Yeterli miktarda } \\
\text { yangın söndürme } \\
\text { ekipmanının } \\
\text { olmaması }\end{array}$ & $\begin{array}{l}\text { İş kazası, yangın, } \\
\text { yaralanma, uzuv } \\
\text { kaybı ve ölüm }\end{array}$ & $\begin{array}{c}\text { Yeterli miktarda } \\
\text { yangın söndürücü } \\
\text { yoktur. }\end{array}$ & 4 & Yüksek & 5 & $\begin{array}{l}\text { Çok } \\
\text { Ciddi }\end{array}$ & 20 & Ciddi \\
\hline & $\begin{array}{c}\text { Çalışma talimatlarının } \\
\text { olmaması }\end{array}$ & $\begin{array}{l}\text { İş kazası, } \\
\text { yaralanma }\end{array}$ & $\begin{array}{l}\text { Yapılacak işle ilgili } \\
\text { çalışma talimatları } \\
\text { yoktur. }\end{array}$ & 3 & Orta & 4 & Ciddi & 12 & Orta \\
\hline & $\begin{array}{c}\text { Uyarı ve ikaz } \\
\text { levhalarının olmaması }\end{array}$ & $\begin{array}{l}\text { İş kazası, } \\
\text { yaralanma }\end{array}$ & $\begin{array}{c}\text { Yeterli miktarda } \\
\text { uyar ve ikaz } \\
\text { levhaları yoktur. }\end{array}$ & 3 & Orta & 4 & Ciddi & 12 & Orta \\
\hline & \multicolumn{3}{|c|}{ ORTALAMA } & 3.5 & Yüksek & 4.5 & $\begin{array}{c}\text { Çok } \\
\text { Ciddi }\end{array}$ & 15.75 & Ciddi \\
\hline
\end{tabular}

Çizelge 11'e göre ilgili işyerindeki, montaj alanı kaynağındaki tehlikelerin olasılık değerinin, en yüksek; yangın algılama sistemi olmaması ve yeterli miktarda yangın söndürme ekipmanının olmaması, en düşük; çalışma talimatlarının olmaması, uyarı ve ikaz levhalarının olmaması olduğu ve bunların ortalama değerlerinin de (3.5) olduğu tespit edilmiştir. Şiddet değerinin, en yüksek; yangın algılama sistemi olmaması ve yeterli miktarda yangın söndürme ekipmanının olmaması, en düşük; çalışma talimatlarının olmaması, uyarı ve ikaz levhalarının olmaması olduğu ve bunların ortalama değerlerinin de (4.5) olduğu tespit edilmiştir. Risk skoru değerinin, en yüksek; yangın algılama sistemi olmaması ve yeterli miktarda yangın söndürme ekipmanının olmaması, en düşük; çalışma talimatlarının olmaması, uyarı ve ikaz levhalarının olmaması olduğu ve bunların ortalama değerlerinin de (15.75) olduğu tespit edilmiştir. 


\subsection{Makineler}

Makineler kaynağındaki tehlike ve risklerin değerlendirilmesine ilişkin bilgiler Çizelge 12 'de verilmiştir.

Çizelge 12. Makineler kaynağındaki tehlike ve risklerin değerlendirilmesi

\begin{tabular}{|c|c|c|c|c|c|c|c|c|c|}
\hline \multirow{3}{*}{$\begin{array}{c}\text { Tehlike } \\
\text { Kaynağı }\end{array}$} & \multirow{3}{*}{ Tehlike } & \multirow{3}{*}{ Risk } & \multirow{3}{*}{ Mevcut Durum } & \multicolumn{6}{|c|}{ Risklerin Değerlendirilmesi } \\
\hline & & & & \multicolumn{2}{|c|}{ Olasılık (O) } & \multicolumn{2}{|c|}{ Şiddet (Ş) } & \multicolumn{2}{|c|}{ Risk Skoru $(\mathbf{O} *$ Ş) } \\
\hline & & & & Değeri & Seviyesi & Değeri & Seviyesi & Değeri & Seviyesi \\
\hline \multirow{5}{*}{ 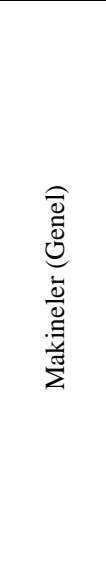 } & $\begin{array}{l}\text { Acil durumda tüm } \\
\text { makineleri aynı } \\
\text { anda durduracak } \\
\text { sistemin olmaması }\end{array}$ & $\begin{array}{l}\text { İş kazası, uzuv } \\
\text { kaybı, yaralanma } \\
\text { ve ölüm }\end{array}$ & $\begin{array}{l}\text { Söz konusu sistem } \\
\text { mevcut olup, } \\
\text { sorunsuz } \\
\text { çalışmaktadır. }\end{array}$ & 2 & Küçük & 5 & Çok Ciddi & 10 & Orta \\
\hline & $\begin{array}{c}\text { Makinelerin } \\
\text { çevresinde, yanıcı } \\
\text { ve patlayıcı olması }\end{array}$ & $\begin{array}{l}\text { İş kazası, patlama, } \\
\text { yangın, uzuv kaybı, } \\
\text { yaralanma ve ölüm }\end{array}$ & $\begin{array}{l}\text { Bazı makinelerin } \\
\text { çevresinde boya ve } \\
\text { tiner tenekeleri } \\
\text { mevcuttur. }\end{array}$ & 5 & $\begin{array}{l}\text { Çok } \\
\text { Yüksek }\end{array}$ & 5 & Çok Ciddi & 25 & $\begin{array}{c}\text { Tolere } \\
\text { Edilemez }\end{array}$ \\
\hline & $\begin{array}{l}\text { Makinelere ait } \\
\text { çalışma } \\
\text { talimatlarının } \\
\text { olmaması } \\
\end{array}$ & $\begin{array}{c}\text { İş kazası, uzuv } \\
\text { kaybı, yaralanma } \\
\text { ve ölüm }\end{array}$ & $\begin{array}{l}\text { Hiçbir makinenin, } \\
\text { çalışma talimatı } \\
\text { yoktur. }\end{array}$ & 4 & Yüksek & 5 & Çok Ciddi & 20 & Ciddi \\
\hline & $\begin{array}{l}\text { Makinelere ait } \\
\text { uyarı işaret ve } \\
\text { levhaların } \\
\text { olmaması }\end{array}$ & $\begin{array}{l}\text { İş kazası, uzuv } \\
\text { kaybı, yaralanma } \\
\text { ve ölüm }\end{array}$ & $\begin{array}{l}\text { Hiçbir makinenin, } \\
\text { uyarı işaret ve } \\
\text { levhaları yoktur. }\end{array}$ & 4 & Yüksek & 5 & Çok Ciddi & 20 & Ciddi \\
\hline & \multicolumn{3}{|c|}{ ORTALAMA } & 3.75 & Yüksek & 5 & Çok Ciddi & 18.75 & Ciddi \\
\hline
\end{tabular}

Çizelge 12'ye göre ilgili işyerindeki, makineler (genel) kaynağındaki tehlikelerin olasılık değerinin, en yüksek; makinelerin çevresinde, yanıcı ve patlayıcı olması, en düşük; acil durumda tüm makineleri aynı anda durduracak sistemin olmaması ve bunların ortalama değerlerinin de (3.75) olduğu tespit edilmiştir. Şiddet değerinin, tüm tehlikelerde en yüksek seviyede olduğu ve bunların ortalama değerlerinin (5)olduğu tespit edilmiştir. Risk skoru değerinin, en yüksek; makinelerin çevresinde, yanıcı ve patlayıcı olması, en düşük; acil durumda tüm makineleri aynı anda durduracak sistemin olmaması ve bunların ortalama değerlerinin de (18.75) olduğu tespit edilmiştir.

Pedis (2018), makinelerin üzerinde kullanım talimatının bulunmaması tehlikesinin risk skorunu 15, daire testerenin güvenlik donanımının olmaması tehlikesinin risk skorunu da 16 olarak tespit etmiştir.

\section{Sonuç ve Öneriler}

İş sağlığı ve güvenliği ile ilgili risk değerlendirmesi; çalışma ortamlarındaki risklerin tespit edilmesi, derecelendirilmesi ve önem arz eden riskler için uygun çözüm önerilerinin üretilebilmesi için yapılan sistematik bir çalışmadır. Risk değerlendirmesi, çalışma ortamlarındaki kaliteyi yükseltmek ve iş kazaları ile meslek hastalıklarını önlemek ya da en aza indirmek açısından çok önemlidir.

Risk belirleme aşamasında, işletmenin çeşitli bölümlerinde, kaygan zemin, uygun olmayan oturuş bozuklukları, çok yükssek sıcaklık, çok düşük sıcaklık, çok yükssek gürültü, yetersiz aydınlatma, düşen objeler, yanlış bilgisayar kullanımı, yüksek elektrik akımı, tehlikeli kimyasal ve biyolojik maddeler, yetersiz temizlik, ağır taşıma ve düzensiz trafik gibi risk faktörleri belirlenmiştir. Belirlenen risk faktörleri için olasılık ve şiddet değerleri saptanmıştır. Nitel risk analizi aşamasında, 5x5 L Tipi Matris metodu uygulanmıştır. Bu yöntemle risk faktörleri için belirlenen olasılık ve şiddet değerleri L Tipi Matris kullanılarak çakıştırılarak; risk skorları belirlenmiştir. Daha sonra, her bölüm için, belirlenen risk faktörlerini, etkilerini, derecelerini, yapılacak eylemi, risklerin giderilmesi için alınacak önlemleri, şiddet, olasılık ve 
risk skoru değerlerini içeren L Tipi Matris Risk Değerlendirme Formu oluşturulmuştur. Bu çalışmanın sonucunda incelenen işletmede aşağıdaki eksiklikler tespit edilmiştir:

- Elektrik pano ve tesisatı ile makinelerin bazı kabloları duvara ya da zemine gömülü vaziyette değildir.

- Yangın algılama ve söndürme ekipmanları yeterli olmayıp, erişilmesi zor olan yerlere konumlandırılmıştır.

- Makinelerde çalışma güvenliği talimatları ile diğer uyarı ve güvenlik levhaları yeterli miktarda değildir.

- Zemin, duvar, tavan ve pencerelerde toz, kir ve az da olsa küf oluşumu gözlemlendiği için sağlıklı çalışma ortamı için pek elverişli değildir.

- Çalışma ortamı aydınlatma, iklimlendirme, havalandırma, gürültü ve titreşim gibi fiziksel çevre faktörleri açısından yeterli olmayıp, çalışan kişiler de bu konuda gerekli duyarlılığa sahip değildir.

- Güvenli yük taşıma ve kaldırmayla ilgili ilkelere çalışanlar tarafından riayet edilmemektedir.

- Acil müdahale yapılması gereken durumlar için, yeterli önlemler alınmamıştır.

- Çalışma ortamı hacim olarak yeterli büyüklüğe sahip olmadığı için işyerindeki bütün birimler birbirine çakışık vaziyette olup, bu durum hem iş kazalarına zemin hazırlamakta hem de kargaşaya sebep olmaktadır.

- İşyerinde yeterli miktarda bulunmasına rağmen; eldiven, kulak koruyucu, gözlük, maske vb. kişisel koruyucu donanım ile işe uygun kıyafet (iş önlüğü) kullanımı çalışanlar arasında pek yaygın değildir.

- Patlaması halinde; çok ciddi maddi kayıplara sebebiyet verebilecek kompresörün, diğer birimlerden bağımsız, kendine has bir odası ile kapısı bulunması gerekirken alan yetersizliği nedeniyle bu imkân sağlanamamıştır.

- Ofis ortamında kullanılan masa ve sandalyeler ergonomik açıdan uygun değildir.

\section{Bu bilgiler ışığında şu önerilerde bulunulabilir:}

- Kutu tipi mobilyalar, büyük ölçülerdeki levhaların işlenmesi suretiyle üretildiği için makineler arasındaki hattın düzgün işleyebilmesi için, bu tip imalathaneler uygun büyüklükte olmalıdırlar.

- Sektörde çalıştırılacak elemanlar bu alanda eğitim almış kişiler arasından seçilmeli, çalışmaya başlamadan önce yeterli düzeyde hizmet öncesi eğitime alınmalıdırlar.

- İşyerlerinde gerekli sağlık malzemeleri eksiksiz biçimde bulundurulmalı, çalışanlar kaza anında ilkyardımda bulunabilecek şekilde eğitilmelidirler.

- İş sağllğ 1 ve güvenliği eğitimlerine önem verilmesi, üniversite ve diğer kurumların ilgili birimleri ile sürekli diyalog halinde bulunulması ve üniversite-sanayi işbirliğini geliştirici çalışmalarda bulunulması gerekli görülmektedir.

- İşyerinde karşılaşılması muhtemel tehlikelere karşı tüm çalışanlar uyarılmalı, eğitilmeli ve bilinçlendirilmelidir. İş güvenliği uzmanı tarafından işletme içinde sürekli denetimler yapılmalı ve bunlar periyodik raporlar halinde üst yönetime sunulmalidır.

- Hijyenik olmayan koşullarda bulunan çalsşanlardan, hem yeterli düzeyde verim elde edilemez hem de bu koşullar nedeniyle ortaya çıkabilecek sonuçların faturası işveren açısından oldukça ağır olabilecektir. Bu nedenle, işyerlerindeki bütün alanların özellikle de mutfak, lavabo ve soyunma odası gibi ortak kullanım alanlarının temiz ve hijyenik olmasına dikkat edilmelidir. 


\section{Teşekkür}

$\mathrm{Bu}$ çalışma, Gazi Üniversitesi Teknoloji Fakültesi Ağaçişleri Endüstri Mühendisliği Bölümü Mezunu Eyüp AKSOY tarafından hazırlanan Lisans Bitirme Tezinden üretilmiştir.

\section{Kaynaklar}

Akça, K., İ., (2016), Mobilya sektörünün iş sağlığı ve güvenliği açısından değerlendirilmesi ve 3t risk değerlendirme yöntemi ile bir uygulama çalışması yapılması, Yüksek Lisans Tezi, Gazi Üniversitesi Să̆lık Bilimleri Enstitüsü, Ankara.

Atılgan, A., Ersen, N., Peker, H., Kahraman, N., (2015), Türkiye mobilya sanayinde iş kazas1 ve meslek hastalıklarının önlenmesine ilişkin tavsiyeler, Selçuk Üniversitesi SelçukTeknik Dergisi, Özel Say1-1 (UMK-2015): 664-683.

ÇSGB 1 , (2012), İş sağlığı ve güvenliği kanunu, Resmi Gazete, 30.06.2012, Sayı: 28339

$\mathrm{ÇSGB}_{2}$, (2012), İş sağlı̆̆1 ve güvenliğine ilişkin işyeri tehlike sınıfları tebliği, Resmi Gazete, 26.12.2012, Say1: 28509

Erdim, H., Türkmen, A., Atalar, C., Tansu, A., (2010), Ahşap doğrama atölyelerinde iş sağ lı̆̆ ve güvenliği el kitabı, Taşova Taş Ocakları Vakfı Yayınları, Lefkoşa, 106.

Ford, M.T., Tetrick, L.E., (2011), Relation among occupational hazards, Attitudes and Safety Performance .Journal of Cccupational Health Psychology, 16(1), 48-66

Kalkan, T., B., (2013), İş sağlığı ve güvenliği risk değerlendirme çalışmaları için bir metodoloji oluşturma ve bir mobilya işletmesinde uygulanması, Yüksek Lisans Tezi, Kırıkkale Üniversitesi Fen Bilimleri Enstitüsü, Kırıkkale.

Koç, S., (2016), Mobilya sektöründe ergonomik risk değerlendirmesi: bir mobilya fabrikasında saha çalışması, Yüksek Lisans Tezi, Hacettepe Üniversitesi Fen Bilimleri Enstitüsü, Ankara.

Özkılıç, Ö., (2005), İş Sağlı̆̆1 ve güvenliği, yönetim sistemleri ve risk değerlendirme metodolojileri, Tisk Yayınları, Ankara, No:246, s.24-151.

Pedis, K., (2018), Ahşap ve mobilya imalatı yapan bir işyerinde risklerin belirlenmesi ve örnek risk çalışması, Yüksek Lisans Tezi, Gümüşhane Üniversitesi Fen Bilimleri Enstitüsü, Gümüşhane.

Semerci, N., T., (2014), Kızılçam işleyen kereste fabrikalarında iş sağlığı problemleri, Yüksek Lisans Tezi, Süleyman Demirel Üniversitesi Fen Bilimleri Enstitüsü, Isparta.

Seyhan, Y., (2009). Ankara ilinde ağaç işleri sektöründe faaliyet gösteren orta ve büyük ölçekli işletmelerde iş sağlığı ve güvenliği üzerine araştırmalar, Yüksek Lisans Tezi, Bartın Üniversitesi Fen Bilimleri Enstitüsü, Bartın.

Sönmez A., Arslan A. R., Asal Ö., Akdere B., (2009), Ankara'da mobilya sektöründe faaliyet gösteren küçük ve orta büyüklükteki işletmelerde fiziksel çevre koşullarından ortam faktörlerinin değerlendirilmesi, Politeknik Dergisi, 2, 127-135.

Şen, H., Çınar, H., (2017), Mobilya ürün yaşam döngüsünde iş sağlığ1 ve güvenliği analizi, Mühendislik Bilimleri ve Tasartm Dergisi, 5(2016), 235-246.

Tor, D., (2015), İş Sağlığı ve güvenliğinde risk analizi: kapı imalat sektöründe bir uygulama, Yüksek Lisans Tezi, Bartın Üniversitesi Fen Bilimleri Enstitüsü, Bartın.

Turan, G., (2013), Mobilya üretimi sürecinde karşılaşılan başlıca önemli çevresel etkilerin 
çalışan sağlığı açısından değerlendirilmesi, Yüksek Lisans Tezi, Namık Kemal Üniversitesi Fen Bilimleri Enstitüsü, Tekirdağ.

Uygun, Z., (2015), Mobilya sektöründe iş sağlı̆̆ ve güvenliğinde riskler ve önlemleri A ve B işletmelerinin İSG uygulamaları yönünden karşılaştırılması, Yüksek Lisans Tezi, Gediz Üniversitesi Fen Bilimleri Enstitüsü, İzmir.

Yılmaz, İ., C., (2012), İş kazalarının analizi (mobilya sanayindeki küçük ve orta boy işletmeler ile büyük boy işletmelerin karşılaştırılması), Yüksek Lisans Tezi, Karabük Üniversitesi Fen Bilimleri Enstitüsü, Karabük.

Yılmaz, K., (2015), Ağaç İşleri endüstrisinde iş sağlığı ve güvenliği ile ilgili mevcut durumun belirlenmesi: mobilya sektörü örneği, Yüksek Lisans Tezi, Hacettepe Üniversitesi Fen Bilimleri Enstitüsü, Ankara. 